\title{
El Género Literario del Martín Fierro
}

Entre los varios interrogantes que plantea el estudio del Martín Fierro el del género acompaña al poema desde las primeras apreciaciones críticas del libro hasta los intentos más recientes por definir su forma literaria. No hay género por cuyo cedazo no se haya intentado hacer pasar a la obra de Hernández: poema épico, rapsodia, drama, elegía, novela, novela picaresca, poema lírico, literatura sapiencial, y finalmente aquellos que prefieren verlo como poema sui generis que desafía toda clasificación. La identidad genérica del libro ha servido propósitos varios, algunos de los cuales tienen muy poco que ver con su condición de obra literaria. En última instancia lo que interesa respecto a su pertenencia a un género es la posibilidad de su mejor comprensión y de su estudio más cabal como creación literatia. Más allái de estos fines, la búsqueda de un género para el poema de Hernández toma visos de intento gratuito cuya esterilidad ilustran no pocas de las tesis que aunque construidas con las mejores intenciones obedecen a un afán extraliterario.

\section{LA CRÍTICA ESPAÑOLA}

Unamuno fue el primero en sugerir que "en Martin Fierro se compenetran y como se funden íntimamente el elemento épico y el lírico". El artículo es de 1894 y apareció en la Revista Española. En una nota más tardía, titulada " $\mathrm{La}$ literatura gauchesca" y publicada en la misma revista, Unamuno insistió en que el "Martinn Fierro es lo más homérico que conozco en la literatura hispanoamericana". Y agregaba: "Don Francisco Soto y Calvo, en los preciosísimos y vigorosos relatos que constituyen sus Cuentos de mi padre, aplica más de una vez el término bomérico a las costumbres gauchescas; y yo que, por virtud de mi profesión de catedrático de lengua y literatura griega, he hecho traducir, comentándolos en mi clase, los viejos cantos homéricos, hallo una perfecta exactitud en la

1 M. de Unamuno, Obras completas (Madrid, 1958), vol. VIII, p. 53. 
aplicación del término".2 Para Unamuno, lo de bomérico quería decir un retorno a lo elemental y primigenio, como él mismo explica más adelante, ${ }^{3}$ pero en cambio dejó sin explicar lo que entendía como el elemento épico del Martín Fierro. No es difícil inferirlo: Unamuno se refiere a ciertos rasgos del poema y no a la exclusividad de un género, como lo prueba el que encontrara por igual elementos de dos géneros - el épico y el lírico- tradicionalmente opuestos dentro del canon de la convención.

También Menéndez y Pelayo, en su Historia de la poesia bispanoamericana, observa que "ni Estanislao del Campo, ni Hilario Ascasubi, ni José Hernández pueden ser clasificados en rigor de payadores ni de poetas populares; hay en sus obras" _agrega_- "mucho dilettantismo artístico, pero la fibra popular persiste, y en este último - Hernándezllegó a manifestarse épicamente". ${ }^{4}$ Tampoco Menéndez y Pelayo explica en qué reside la calidad épica del Martín Fierro, pero la forma adverbial empleada para definir lo popular del poema deja entrever que aludía más bien a ciertos rasgos que a su género literario.

\section{MARTín FiERro EPOPEYA}

Estas alusiones a lo épico y a los poemas homéricos debieron estimular a Lugones. El payador (1916) representa hasta hoy el intento más ambicioso por definir al poema de Hernández como epopeya. En el prólogo anticipaba Lugones: "El objeto de este libro es, pues, definit bajo el mencionado aspecto la poesía épica, demostrar que nuestro Martín Fierro pertenece a ella, estudiarlo como tal, determinar simultáneamente, por la naturaleza de sus elementos, la formación de la raza, y con ello formular, por último, el secreto de su destino". ${ }^{5}$ El interés de Lugones por demostrar la filiación épica del poema parece residir menios en su realidad literaria que en la posibilidad de derivar de él un ideario nacional. Este interés nace en gran parte de su concepto de la poesía épica: "Y es que la poesía épica" -escribe Lugones- "tiene como objeto específico el elogio de las empresas inspiradas por la justicia y la libertad. Con esto, al ser ella la expresión heroica de la raza, defínese por conceptos

\footnotetext{
2 Ibid., p. 90.

3 En página 92 del mismo artículo, escribe: "Y el gaucho, como todo tipo sencillo, es profunda y homéricamente poético".

4 Marcelino Menéndez y Pelayo, Historia de la poesia bispanoamericana (Santander, 1948), vol. II, p. 396.

5 Leopoldo Lugones, El payador en Obras en prosa (Madrid, 1962), p. 1082. Citas subsiguientes por esta edición.
} 
de patria y civilización, coincidentes, como acaba de verse, en ese doble anhelo de excelencia humana: la justicia y la liberta'd" (p. 1089). Más adelante prescribe, otra vez, que "lo más importante en la poesía épica es el carácter, o sea el espíritu que la anima y le da su significado trascendental" (p. 1100). Los aspectos de forma inherentes al género son para Lugones meros "rasgos exteriores que provienen de ese estado espiritual" (p. 1100). Esos rasgos exteriores consistirían, según Lugones, en "la caracterización nacional" y "la inspiración religiosa". Del primer rasgo se desprende que "toda poesía empieza a ser épica apenas resulta inevitablemente nacional" (p. 1101); y del segundo, que "la poesía épica vendría a ser un fenómeno religioso" (1103) Hasta qué punto estos rasgos son exteriores, Lugones no nos lo explica. En el capítulo titulado "Martin Fierro es un poema épico", se propone demostrar su hipótesis recurriendo a argumentos a veces rebuscados, como la anécdota "de un gaucho viejo que vivia solo con su mujer en cierto paraje muy solitario de las sierras cordobesas" (1257), y otras, traídos de los pelos, como su alusión al lenguaje de formación reciente de la Divinia Comedia lo cual lo hermanaría con el lenguaje "de rudos pastores" del poema de Hernández.

A Lugones debió molestarle el estilo solemne y elevado del género épico o el uso de ciertas formas métricas en los poemas de ese género. Cuando esto ocurre, el autor de $E l$ payador se vuelve contra la retórica: "El canon retórico" - escribe- "que pretende limitar la expresión épica al hexámetro y al endecasílabo, es una prescripción de eruditos, empeñados en decretar bajo leyes inamovibles la imitación retórica. No tiene otro objeto ni otra razón; pues allá donde existan ideas y sentimientos épicos, que es decir, una vida heroica expresada con el lenguaje musical que constituye la poesia, materialmente hablando, hay poesía épica, quiéralo o no la retórica" (p. 1108). Lugones, pues, niega esa preceptiva cuyos cánones establecen el género que Lugones se esfuerza en demostrar para el Martín Fierro como poema épico, y más que pensar en un género literario piensa en esas obras que mejor representan el carácter y la cultura de un pueblo. Solamente así se explica que haya dicho del Quijote que "sería una creación completa del género épico si no estuviera escrito en prosa" (p. 1097).

Lo que es una reserva en Lugones, deja de serlo en Ricardo Rojas, para quien el Quijote es una epopeya y la poesía épica argentina se inicia con el folklore de los campos y en los versos de los payadores. Rojas ya no ve necesidad alguna en demostrar el género del Martín Fierro. Lo que para Lugones era todavía una tesis audaz, se ha convertido para Rojas en verdad axiomática. Su tarea consiste en elaborar una teoría del 
género según la cual el folklore, las leyendas, los refranes, las adivinanzas, las anécdotas del hombre de campo argentino forman su poesía épica oral de la que nacen sus epopeyas, que Rojas distingue de la épica oral porque en aquéllas "el hombre se hace el centro del relato, dejando" -explica- "abajo de sí los seres inanimados y encima de sí las fuerzas divinas de la naturaleza, aunque conservando con ellos una oculta solidaridad". "Para Rojas no sólo el Santos Vega de Ascasubi y el Martín Fierro son epopeyas, también el Facundo de Sarmiento pertenece a la épica. ${ }^{7}$

REACCIÓN CONTRA EL MITO ÉPICO

En ese escrutinio de la crítica del Martín Fierro que es el capítulo que cierra el primer volumen de Muevie y transfiguración del Martin Fierro, Martínez Estrada distingue dos generaciones de críticos del poema. La primera formada por los contemporánecs de Hennández - Manuela Gorriti, Mitre, Miguel Cané, José Manuel Estrada, Nicolás Avellaneda, Juan María Torres-, y la segunda que escribe después de la euforia nacional de las fiestas del Centenario. En la primera, Martínez Estrada diferencia dos fases: una de desdén hacia el poema y otra de olvido. Juan María Gutiérrez, por ejemplo, ni siquiera juzgó necesario comentar la aparición del poema. "En 1880" —escribe Martínez Estrada - "el Martín Fierro es una obra arqueológica, y los críticos, empeñados en repetir la empresa de crear una cultura con lo bueno de nuestra tierra y con lo bueno de las letras extranjeras, en el plan del Salón Literario, enmudecen". ${ }^{8}$ "La crítica del Poema se detiene en el umbral de esa 'nueva realidad' - el anhelo unánime de prosperidad y paz se convierte en bien actual-y casi inmediatamente el hombre culto le da la espalda". 9

La segunda generación crea el mito de la epopeya. El corifeo es Lugones y tras él Rojas, Leguizamón, Gálvez, Tiscornia y Leumann celebraron el hallazgo y lo justificaron. "Casi todos los críticos posteriores a las disertaciones y lecturas de Lugones' - escribe Martínez Estrada"han seguido sus pautas. Podemos fijar, sin ninguna duda, la cristalización del Martín Fierro como mito, en aquellas épicas jornadas oratorias del teatro Odeón. Las pautas estaban en realidad trazadas de antemano,

${ }^{6}$ Ricardo Rojas, Historia de la literatura argentina. Los gauchescos (Buenos Aires, 1949), vol. I, p. 219.

7 Ibid., p. 204.

8 Ezequici Martínez Estrada, Muertei y transfiguración del Martin Fierro (México, 1958), vol. I, p. 435. Citas subsiguientes incluyen volumen y página solamente.

9 Ibid., págs. 434-435. 
para Lugones, no en la crítica sino en la literatura nacional. Lugones concreta, aplicándola al Martín Fierro, la eterna tendencia nuestra a deificar alguna figura, no por el espíritu de veneración, sino por necesidad de poseer un héroe, un santo o un sabio en quienes creer" (I, 423).

Una tercera generación de escritores argentinos inmediatamente posterior a la de Rojas y Lugones se abocará a la tarea de rebatir la tesis consagrada por la generación anterior y a demoler sistemáticamente el mito. Calixto Oyuela, Borges y Martínez Estrada, aunque no los únicos, representan lo más acervo de la crítica contra el supuesto género épico del poema. En su Antología poética bispanoamericana (1919-1920), Oyuela arremetió contra Lugones y Rojas. En la nota crítica dedicada a Hernández, escribe: "El mayor desbarro que últimamente se ha cometido con respecto a Martín Fierro, se refiere a su clasificación poética. En vez de estudiarlo profundamente en si, en sus métodos y caracteres individuales y sui generis, se ha querido engrandecerlo y glorificarlo por medio de falsas y ambiciosas analogías, encasillándolo, no filosófica sino retóricamente, en una de las más altas y excepcionales categorías poéticas conocidas: la epopeya primitiva y genuina. Apenas puede concebirse más vano empeño que el de tal asimilación". ${ }^{10}$ Oyuela explica, sin reticencias, que si "la epopeya genuina es un género constituido por ciertos elementos fundamentales, esos elementos faltan del todo en Martin Fierro". Y continúa: "Nuestro hermoso Poema gauchesco contiene, sin duda, elementos épicos reflejos, pero nada tiene que ver con la verdadera epopeya, ni por su asunto, ni por su medio, ni por su época, ni por su tipo central, ni por su procedimiento, ni por su tendencia, ni por su lenguaje, ni por su autor" (II, 142). Oyuela procede a demostrar por el absurdo la inconsistencia de los argumentos con que se había defendido la tesis épica. Las razones aducidas por Oyuela pueden resumirse en torno a seis puntos: asunto, argumento, héroe, empresa, procedimiento y lenguaje. De cada uno de ellos, Oyuela explica:

1. El asunto de Martín Fierro no es propiamente nacional, ni menos de raza, ni se relaciona en modo alguno con nuestros orígenes como pueblo ni como nación políticamente constituidd. Trátase en él de las dolorosas vicisitudes de la vida de un gaucho, en el último tercio del siglo anterior, en la época de la decadencia y próxima desaparición de ese tipo local y transitorio nuestro, ante una organización social que lo aniquila (p. 143).

2. A cualquiera se le ocurre que la base o argumento de un poema

10 Calixto Oyuela, Poetas bispanoamericanos (Buenos Aires: Academia Argentina de Letras, 1948), vol. II, p. 141. 
o canción de gesta nacional ha de ser, necesariamente, una empresa nacional o de raza, de carácter colectivo. Pero de ello no hay ni rastros en Marín Fierro, cuya acción se refiere a un caso individual, a las desdichadas aventuras de un gaucho matrero alzado contra la autoridad (pp. 144-145).

3. No menos ajeno a una verdadera epopeya popular es el béroe de nuestro poema. Tampoco en él hay esa idealización instintiva y legendaria, que sin desvanecer el vivo sello individual, lo depura y eleva a una alta representación general, dándole cierto espontáneo valor simbólico (p. 146).

4. La empresa de Martin Fieno es personal, y no colectiva, lo que hace de él un personaje representativo de novela o de drama, y no de epopeya (pp. 147-148).

5. El procedimiento de relato autobiográfico, contado y cantado por el mismo protagonista, es todo lo más inadecuado que cabe imaginar en una epopeya. ¿Cómo ha de conservar la objetividad, la serenidad, la impersonalidad épica, tan esenciales al género, quien cuenta sus propias desdichas, su vida deshecha, alternando necesariamente el relato con el lamento elegíaco a la protesta indignada? (p. 148).

6. El lenguaje del poema es otro elemento que depone en contra del pretendido carácter genuinamente popular del mismo, como verdadera epopeya. No es ese lenguaje el que el pueblo y su órgano poético usan en común, identificándose espontánea y espiritualmente con él, sino una deliberada imitación del habla vulgar gauchesca, inculta y retardada, por un poeta culto, que habla y escribe generalmente en buen castellano (p. 149).

Oyuela concluye que "poco supone que el Martin Fierro no sea lo que absolutamente no podría ser, con tal asunto y en tal época, una poesía popular ex integra cousa, una genuina epopeya: nos basta con que sea un hermoso poema sui generis, semi-popular y semi-artístico, un caso admirable de interpretación y penetración del alma gauchesca por un poeta culto. . L Lo que nos importa es esa mezcla de elementos épicos y líricos, bélicos y elegíacos, con que se narra y expresa a la vez, describiéndola y sintiéndola, una conmovedora tragedia individual y colectiva, llena de fuerza y carácter" (p. 158). Oyuela rechaza, así, la pertenencia del poema a un género exclusivo para aceptar elementos de casi todos. Directa o indirectamente atribuye al poema rasgos peculiares de la novela, el drama, la elegía, la tragedia, la lírica y -por supuesto- la épica. ${ }^{11}$

11. No otra es la solución sugerida por John B. Hughes para quien hay "cinco géneros posibles que podrían definir el poema -epopeya, largo poema lírico, novela, drama y parábola-, pero aunque el Martín Fieyro tolera elementos afines 
Borges retoma la polémica con el mismo espíritu de Oyuela, a quien cita y cuyos juicios, al menos parcialmente, comparte. En su ensayo sobre "La poesía gauchesca" incluido en Discusión (1932) resume, con el tono sardónico del primer Borges, los "méritos" de la crítica en torno al Martin Fierro. En un breve pártafo, que después recogerá Martínez Estrada, escribe: "Sospecho que no hay otro libro argentino que haya sabido provocar de la crítica un dispendio igual de inutilidades. Tres profusiones ha tenido el error con nuestro Martín Fierro: una, las admiraciones que condescienden; otra, los elogios groseros, ilimitados; otra, la digresión histórica o filológica". ${ }^{12}$ Borges arremete, a renglón seguido, contra el método "de pesquisar versos contrahechos o ingratos en las epopeyas antiguas como si las afinidades en el error fueran probatorias", directa referencia a Lugones y a sus intentos de hermanar el Martin Fierro con la Divina Comedk. "Ese operoso manejo" - continúa Borges- "deriva de una superstición; presuponer que determinados géneros literatios (y en este caso particular, la epopeya) valen formalmente más que otros. La estrafalaria y cándida necesidad de que el Martín Fierro sea épico ha pretendido comprimir, siquiera de un nodo simbólico, la historia secular de la patria, con sus generaciones, sus destierros, sus agonías, sus batallas de Tucumán y de Ituzaingó, en las andanzas de un cuchillero de mil ochocientos setenta. Oyuela" - concluye Borges- "ha desbaratado ya ese complot' (D., 32).

En una elaboración más tardía de este ensayo, publicada bajo el título El Martín Fierro (1953), Borges emplea un tono más conciliatorio y busca explicar los esfuerzos y propósitos de la crítica por convertir el poema de Henández en epopeya nacional. "El concepto de que cada país debe tener un libro" -escribe- "es muy viejo y al principio fue de índole religiosa... Del concepto de libro canónico religioso se pasó, a comienzos del siglo xxx, al de libros canónicos nacionales; Carlyle escribió que Italia se cifraba en la Divina Comedia y España en el Quijote y agregó que la casi infinita Rusia era muda, porque aún no se había manifestado en un libro. Lugones declaró que los argentinos ya poseíamos ese libro canónico y que éste, previsiblemente, era el Martin Fierro". ${ }^{13}$

a cada uno de esos géneros, se resiste a una identificación exclusiva con uno de ellos. "Ninguna descripción genérica hasta ahora avanzada" - concluye Hughes"agota la totalidad de la obra ni, a fin de cuentas, es completamente fiel a la realidad descrita". (John B. Hughes, "El géneto del M. F.", La Nación, sept. 29 de 1963. Citado por Noé Jitrik en Historia de la literatura argentina (Buenos Aires: Centro Editor de América Latina, 1967), p. 361.

12 J. L. Borges, Discusión (Buenos Aires, 1932); p. 31.

13 Jorge Luis Borges, El Martín Fierro (Buenos Aires, 1953), p. 58. También Rojas había escrito en Los gauchescos: "El Martinn Fierro llega, por su unidad y por su asunto, a ser para la nación argentina algo muy análogo a lo que es para 
Borges convirtió así el mito épico en superstición -una superstición en la que hoy muy pocos creen-y propuso la novela como el género que mejor definía al poema.

Martín Fierro Novela:

"Novela" —escribe Borges en el ensayo de 1932—, "novela de organización instintiva o premeditada, es el Martín Fierro: única definición que puede trasmitir puntualmente la clase de placer que nos da y que condice sin escándalo con su fecha. Esta, quien no lo sabe, es la del siglo novelístico por antonomasia: el de Dostoievski, el de Zola, el de Butler, el de Flaubert, el de Dickens... Se me recordará que las epopeyas antiguas representan una preforma de la novela. De acuerdo, pero asimilar el libro de Hernández a esa categoría primitiva, es agotarse inútilmente en un juego de fingir coincidencias (alusión a los cotejos de Lugones del poema de Hernández con la Divina Comedia), es renunciar a toda posibilidad de un examen. La legislación de la épica -metros heroicos, intervención de los dioses, destacada situación política de los héroesno es aplicable aquí. Las condiciones novelísticas, sí lo son" (D., 37-38). En el prólogo a la edición de Poesía gauchesca en colaboración con Bioy Casares, de 1955, se insiste, aunque menos enérgicamente, en esa idea: "Pese a la estructura métrica y a algunos toques épicos o elegíacos, la obra deja un sabor de novela. Una voluntad laudatoria y la creencia supersticiosa en la primacía del género épico han inducido a muchos críticos a clasificar el Martín Fierro como epopeya. Ello es erróneo... La novela, en su doble carácter de una época y de plena declaración de un destino, estái ilustremente dada en el Martin Fierro". ${ }^{14}$

Pero la crítica más devastadora del mito épico vino de Martínez Estrada. Haciendo trampolín en el párrafo citado del ensayo de Borges, Muerte y transfiguración del Martin Fierro rechaza no solamente la tesis de Lugones y los aditamentos de Ricardo Rojas, sino la mayor parte de la crítica oficial y académica del poema. Para Martínez Estrada ya no se trata tan sólo de demostrar que el Martin Fierro no es epopeya sino de descubrir las intimas motivaciones que habían movido a Lugones y a los demás críticos de su generación a levantar el mito y a dejar intocado el libro de Hernández. "La inutilidad de todas aquellas críticas" - dice Martínez Estrada-, "sin ninguna excepción, no es la demostración de la incapaci-

la nación francesa la Cbanson de Roland y el Cantar de Mío Cid para la nación española". Op. cit., I, 55.

${ }_{14}$ J. L. Borges y A. Bioy Casares, Poesía gaucbesca (México, 1955), pp. XXI-XXII. 
dad de la crítica literaria, es la incapacidad de entender nuestra propia vida histórica y cultural". ${ }^{15}$ La crítica de los críticos, de Martínez Estrada, constituye la demostración de la que Borges había definide lacónicamente como "un dispendio de inutilidades". De Lugones, dice Martínez Estrada:

El payador, que no se refiere sino incidentalmente al Poema, es el cuño en que se funde la nueva efigie de aquel patriotismo de destierro que campea después en toda obra de rehabilitación del Poema. Desde ese momento el Poema queda convertido en cantera de nacionalidad, y los críticos ulteriores se encaminan a esos yacimientos, mejor que al texto, para cohonestar una concepción épica de la historia que, de la Independencia acá, no tiene otro héroe a que acudir sino ese pobre cantor y peleador que, en lugar de ser un héroe, sólo viene a representar un papel heroico de la gesta. (I, 436-437).

$\mathrm{Y}$ en otro lugar agrega: "E1 Martin Fierro que resucitan Lugones, Rojas y Leguizamón trae una misión: es otra vez un redentor; sólo que si antes lo fue de la abyecta condición 'del gaucho, ahora lo será de la tradición, de las virtudes caballerescas del hijo de la tierra" (I, 436).

Su juicio sobre Tiscornia no es más atemperado:

La crítica de Tiscornia no es crítica, sino prurito de justificar y enaltecer; su análisis no es sino la búsqueda de valores académicos y cidianos en el Poema; su hermenéutica es de tal superficialidad que asombra - y arredra- pensar que tal sea la autoridad mayor en esas materias, pues se trata de simples exámenes gramaticales del tipo corriente en la enseñanza media. ( $($, 424).

$Y$ en Leumann, finalmente, ve la culminación de ese proceso de mitificación iniciado por Lugones:

En el libro de Leumann $E l$ poeta creador encontramos en Martín Fierro al hombre religioso, justiciero, bondadoso, ordenado, servicial; encontramos el personaje de cera, la imagen de aquel altar aunque esculpido con manos inhábiles y faltas de fervor. Mañana otro evangelio dará al ícono rasgos que convengan mejor a la imagen pasional en potencia, y entonces ese evangelista del Martín Fierro verá la Verónica. El proceso de cristalización mítica del Mar-

15 Ezequiel Martínez Estrada, Muerte y transfiguración del Martín Fierro (México, 1958), vol. I, 429. 
tin Fierro es paralelo a la necesidad de un mito que encarne la nacionalidad. (I, 432).

Esta crítica, según Marćnez Estrada, más que intentar comprender el poema, le rinde un culto desmesurado que termina ahogándolo en elogios, como la genetación anterior lo hundió en el silencio y el olvido: "Lo más real que tenemos en la literatura" - dice-- "pasa a ser un instrumento al servicio de la mistificación y el engaño. Pasa a ser un ícono en el que se depositan ofrendas, pero en el que nadie cree... Para adorarlo era necesario embalsamarlo, y me duele decir que ese trabajo de taxidermia lo realizó, después de muerto el hombre por otros, Tiscornia. Con paja donde tuvo las vísceras y las glándulas, su fetiche fue llevado con pompa funeraria a la Academia; Tiscornia y él entraron juntos" ( $I, 432,433-434$ ).

E1 libro de Martínez Estrada es, como ha dicho de él Borges, "menos una interpretación de los textos que una recreación; en sus páginas un gran poeta que tiene la experiencia de Melville, de Kafka y de los rusos, vuelve a soñar, enriqueciéndolo de sombra y de vértigo, el sueño primario de Hernández". ${ }^{16}$ Su propósito más ostensible es recuperar esa realidad de la vida argentina encerrada en el poema. Su hostilidad y amargura hacia la crítica emerge de lo que para Martínez Estrada esa crítica ominosamente se propuso: convertir en héroe a Martín Fierro para vaciarlo de su más honda realidad. En uno de los párrafos más memorables de su libro Martínez Estrada resume su filosofía en torno a la crítica del poema: "Lo que no tolerábamos era el estado social abominable que deformaba al gaucho, y por eso concluimos no toletándolo a él. Para crucificarlo, antes lo coronamos como a un rey. Era preciso optar entre ese estado social y político abominable o su víctima. Mitificar a Martín Fierto, abstraerlo de ese mundo, era olvidar ese mundo, cerrar los ojos ante su triste espectáculo" ( $I, 296)$.

A la hora de definir el género del Martín Fierro, Martínez Estrada observa atinadamente: "Es de todos puntos de vista inútil intentar clasificar una obra tan desordenada y compleja dentro de un género tradicional, elegía, relato, sátira, novela, epopeya bárbara, pues sus elementos humanos y anecdóticos han sido recogidos y acumulados con arreglo a un plan impreciso de denunciar atropellos e injusticia, y de fijar al mismo tiempo la psicología del habitante de las fronteras intranacionales" (I, 216). Sin embargo, Martínez Estrada se adhiere al punto de vista de Borges, y de Gerchunoff, quien había anotado que "la naturaleza épica del Martin

16 J. L. Borges, El Martín Fierro, op. cit., p. 60. 
Fierro nace de su fondo de novela, en que el poeta ha logrado crear un tipo". ${ }^{17}$ Ascasubi había llamado a su Santos Vega "historia, poema, o cuento". "Historia, poema, o cuento" - -dice Martínez Estrada- "son alternativas aplicables exactamente al Martín Fierro. Descartada la forma y parcialmente el lenguaje de tropos y el énfasis, el material vivo y el espiritu lúcidamente analítico del autor son de naturaleza novelística... Los materiales novelísticos se han acumulado en torno a un hombre que se sincera, pero son de tal magnitud y se hallan distribuidos con un interés objetivo tan grande, que el Poema asume definitivamente la estructura de una novela de curiosísimas particularidades" ( $I$, 218-219). ${ }^{18}$ "Las dotes de narrador de Hernández" — concluye Martínez Estrada- "dan a la obra un carácter eminentemente objetivo y visual que concurrre a fijar, más que la forma de la novela, la técnica novelística, que no es otra que la de la novela picaresca, aunque el lenguaje de una poética sin compromisos con la poesía la sitúe más acá de su floración naturalista de fines del siglo Xrx" $(I, 220)$.

"Personaje de novela" había dicho Oyuela de Martín Fietro; el Poema "deja un sabor de novela" dice Borges; "fondo de novela" propone Gerchunoff; "técnica novelística" prefiere Martínez Estrada. El entusiasmo por la novela como el género más afín al poema nace quizás de una preocupación y un interés en los valores literarios del Martín Fierro. Frente a la generación de Lugones, que glorifica al poema por razones extraliterarias ("es que la épica constituye un fenómeno nacional, más que un acontecimiento literario", había escrito Lugones en El payddor), la generación siguiente busca recuperar el texto, desmitificarlo y devolverlo a la literatura. Tal vez en ese esfuerzo se explica su preferencia por la novela, un género que no tiene el prestigio de la épica, el linaje de la lírica, o la tradición del drama. Un género más bien nuevo que aún hoy, y seguramente en tiempos de Rojas y Lugones, se asocia "con el entretenimiento, el esparcimiento y la evasión". El carácter de literatura de ficción de la novela subraya, más que en los géneros tradicionales, su condición de irrealidad. ${ }^{19}$ Pero seria un ertor inferir que la simpatía por ese género nace solamente de un sentimiento de reacción hacia las

17 Citado por Martínez Estrada en op. cit., I, 217.

$18 \mathrm{Y}$ sin embargo líneas más atrás había escrito: "A pesar de sus peripecias, el tono fundamental del relato del protagonista, hasta el canto $\mathrm{X}$ de Ia Ida $\mathrm{y}$ hasta el XI de la Vuelta, es lírico; pero a esa altura de cada plarte toma decidi. damente una estructura dramática con la incorporación de nuẻvos interlocutores que traen el argumento sus propias experiencias y modos de conducta". (I, 217).

${ }_{19}$ Un filósofo como Emerson no podía tomar en serio la novela porque la acción le parecía irreal, y Vélez Sársfield, que confesaba con cierta vanagloria no haber leído el Quijote y que no tenía el mínimo deseo de leerlo, consideraba las novelas como cosa insustancial y vana. (Citado por Carlos Alberto Leumann en La literatura gauchesca y la poesia gaucba (Buenos Aires, 1953), p. 56. 
debilidades de la crítica anterior. El poema tiene, sin duda, elementos novelísticos —como los tiene dramáticos, épicos, elegíacos o líricos- y Borges y Martínez Estrada buscaron definir al poema desde ese género eminentemente literario. Este último, por ejemplo, ha indicado "diversas técnicas dentro de su forma nartativa", y "Ia poesía de la obra" — según él- "surge de una exuberancia de su facultad de contar". También ha observado que "los dichos y las metáforas contribuyen a destacar la acción y el aspecto plástico —cuasi psicológico- del relato" ( $(I, 220)$. Entre los defensores del género novela, sin embargo, nadie ha notado que Martín Fierro como personaje representa a ese tipo humano que produce la novela al tomar el lugar de la épica: el anti-héroe. Ningún rasgo como la condición de anti-héroe de Martín Fierro lo convierte tan inequivocamente en personaje de novela más que en héroe de epopeya. Contrariamente, Martínez Estrada pareciera sugerir que "la pobreza del argumento", "la desconexión de unos episodios con otros", y la función de lo lírico "como argamasa para unir esos bloques independientes" son factores que reducen su condición de novela, cuando en realidad constituyen rasgos distintivos, y a veces abusados, de la novela contemporánea.

\section{LA GAUCHESCA COMO GÉNERO LITERARIO:}

Martínez Estrada sin embargo no intenta definir al poema como novela. Indica su técnica novelística pero, en cuanto a su género, se niega a "clasificar obra tan compleja dentro de un género tradicional". No así Borges, para quien el Santos Vega de Ascasubi es "novela métrica"20 y el Martin Fierro, novela, "descontando" — agrega- "el accidente del verso". Pero, ¿es realmente un accidente? ¿No responde más bien a la esencia misma de ese tipo de poesía que todos coinciden en llamar gauchesca? ¿Por qué empeñarse en asimilarlo a un género tradicional? Martínez Estrada ya había advertido sobre la inutilidad de tal empeño, y Oyuela, no sin valentía, había declarado que "importa muy poco que el Martin Fierro no sea absolutamente lo que no puede ser - una obra de género tradicional". Lo más paradójico en esta búsqueda de un género para el Martin Fierro es que desde Rojas en adelante casi todos los críticos y comentaristas del poema condescienden en definirlo - lapsus linguaedentro del único género al cual naturalmente pertenece: el género gau-

20 El Martín Fierro, op. cit., p. 13. También Martínez Estrada sostiene que "el Santos Vega es una novela descriptiva, con diálogos incidentales, aunque esté también contada casi toda ella por Santos Vega. El estilo de este payador difiere del de todos los poemas gauchescos de Hidalgo; al convertirse en monólogo, insensiblemente pasa a la forma narrativa del que escribe, no del que habla" $(I, 162)$. 
chesco. En la Introducción a Los gauchescos, Ricardo Rojas habla del género gauchesco con cierta ligereza e imprecisión y sin ningún ánimo de aceptar ese género que él mismo postula inadvertidamente. "Bartolomé Hidalgo" -escribe- "había sido el precursor nominal de la poesía gauchesca en el Plata; pero ya el género existía desde los romances que se inspiraron en las invasiones inglesas, y acaso esté en ellos el lazo que lo liga a los elementos de la poesía popular" (I, 55). Martínez Estrada, en el extenso capítulo de su libro, titulado "Lo gauchesco", se refiere a esas obras como poesía gauchesca pero reconoce en ésta los trazos que delinean un verdadero género: "Así como lo clásico y lo romántico" -escribe- "expresan no propiamente escuelas, sino más bien temperamentos y directivas de la psique en la vivencia del fenómeno literario, artístico y aun científico, sino también una época, un modo de sentir y de comprender la figuración espiritual o plástica del mundo de las formas, así lo gauchesco es una posición total de la psique: un estilo, un contenido, un uso del lenguaje, una cualidad étnica, un cariz geográfico y temporal, un mundo" (I, 278). Este capítulo representa uno de los intentos más serios de caracterización y fijación de límites y alcances del género gauchesco y de él habrá que partit para la formulación de su poética. Martínez Estrada prefiere para esas obras el nombre de "lo gauchesco", o "poesía gauchesca", o "literatura gauchesca", u "orbe gauchesco", pero en algún lugar las llama también obras del género gauchesco. Lo que importa en realidad es que cuando Martínez Estrada emplea cualquiera de esas denominaciones para anotar lo peculiar de lo gauchesco va definiendo su calidad de género literario y la necesidad de estudiarlo como tal.

También Oyuela ya había llamado a Hidalgo "fundador del género gauchesco". ${ }^{21}$ Borges y Bioy Casares, que rcúnen en dos cuidadosos volúmenes lo más valioso de la poesía gauchesca - produciendo así un instrumento de trabajo fundamental para abordar el estudio sistemático del género-, escriben en la primera línea del prólogo: "En las literaturas de América, el género gauchesco constituye un fenómeno singular", para explicar más adelante que solamente Argentina y Uruguay "han producido un género análogo al género gauchesco".22 Hoy no sorprende encontrar en comentarios y manuales el empleo de género como denominación corriente de la poesía gauchesca. ¿Significa esto que el problema del género del Martin Fierro ha desaparecido? No, lamentablemente. Aunque el uso del término género en relación a la poesía gauchesca se ha generalizado convirtiéndose en una casi convención, tal uso no implica, sin

21 Calixto Oyuela, Poetas hispanoamericanos, op. cit., vol. I, p. 81.

22 J. L. Borges y A. Bioy Casares, Poesía gaucbesca, op. cit., I, vii. 
embargo, el sentido de categoría literaria que tiene dentro de la "teoría de los géneros". Su empleo está restringido a la acepción más corriente de clase o tipo o simplemente grupo de obras. Borges y Bioy, por ejemplo, que en el prólogo citado aluden sin ambages a la poesía gauchesca como género, sostienen hacia el final que el Martín Fierro es una novela.

Premisas para una pó́tica del género gauchesco:

Nuestro resumen de la polémica en torno al género del Martin Fierro muestra que tanto la tesis épica como la tesis novelística resultan, a la larga inconducentes; tienen, como decía Borges en otro contexto, la virtud de eliminar el problema no de resolverlo. Cuando el empeño de clasificación de una obra dentro de un género conduce a errores y extravíos comenzamos a dudar del sentido de tal empeño. La teoría de los géneros es en sí misma una larga historia de confusiones y equívocos desde Aristóteles en ádelante. Para Dante la Eneida era una tragedia y ya se sabe que llamó a su propio poema "comedia". Durante el Renacimiento, Giordano Bruno declaró, sin más, que "hay tantos géneros en poesía como hay poetas", y algunos críticos románticos favorecieron la fusión de todos loś géneros en uno solo. Friedrich Schlegel previó la abolición de todas las definiciones y clasificaciones por género. Croce, finalmente, consideró a los géneros meras abstracciones útiles en la construcción de clasificaciones para comodidad práctica pero sin valor como categorías estéticas. ${ }^{23}$ Sin embargo, la teoría de los géneros no ha dejado de influir poderosa y eficazmente en los estudios literarios. Por supuesto que el concepto de género literario tal como hoy lo entendemos dista leguas del purismo griego o del autoritarismo neoclásico. La distinción entre los llamados "géneros fundamentales" y "géneros subordinados" ha dejado de tener sentido y para Wellek "esas subdivisiones de grupos de segundo orden son los que generalmente entenderíamos hoy por géneros". ${ }^{24}$ Del siglo XIX en adelante nacen nuevos géneros, es decir obras que no pueden encasillarse en los géneros tradicionales. La novela de terror, por ejemplo, que "se inicia en el siglo XvIII, con El castillo de Otranto y llega hasta los tiempos actuales, constituye" — para "Wellek"un género según todos los criterios que cabe invocar para un género de narración en prosa: presenta no solamente un asunto o temática limitada y continua, sino también un repertorio de artificios (descriptivos y narra-

23 Véase el artículo "Genres" en Encyclopedia of Poetry and Poetics. Edited by Alex Preminger (Princeton University Press, 1965), pp. 307-309.

24 Rene Wellek y Austin Warren, Tearia literaria (Madrid, 1959), p. 275. 
tivos, tales como: castillos en tuinas, horrores católico-romanos, retratos misteriosos, pasadizos secretos en los que se penetra por paredes giratorias, raptos, encarcelamientos, persecuciones a través de selvas solitarias); hay, además, un Kunstwollen, una voluntad artística, un empeño estético, un propósito de prowocar en el lector una clase especial de horror y de emoción placenteros": ${ }^{25}$ En mayor o menor medida, todos esos rasgos que según Wellek bastarian para hablar de un género, se dan en la gauchesca. Si un género literarió debe entenderse "como una agrupación de obras literarias basadas teóricamente tanto en la forma exterior (metro o estructura específicos) como en la interior (actitud, tono, propósito)", ${ }^{26}$ el único género posible para el Martín Fierro es el género gauchesco. La importancia de tal definición rebasa un mero propósito clasificador. Debe entenderse como un primer paso hacia un estudio más concienzudo del poema y hacia una comprensión más íntima de su funcionamiento como obra literaria.

El estudio de la poesía gauchesca como un grupo de obras que of recen claros trazos comunes arranca de Lugones. Era imposible evitar la mención de obras que presentaban una relación obvia con el poema de Hernández, aun cuando en el caso de Lugones le recordaran demasiado crudamente los humildes orígenes del personaje que se buscaba glorificar. Así se entiende que escribiera de toda la poesía que precede al Martin Fierro: "Fueron, por así decirlo, jácaras familiares, análogas a las coplas de los juegos de prendas; y es insigne fruslería empeñarse en darle importancia clásica como literatura nacional". ${ }^{27} \mathrm{Y}$ sin embargo, algo de lo que hizo Lugones en $E l$ patyador - disminuir el valor de los demás poemas gauchescos para enaltecer el Martín Fierro- ha sido repetido, aunque en grado, con intenciones y objetivos diferentes, por sus continuadores, tal vez porque, como Borges ha observado con respecto al poema de Hernández, "se confunde la virtud estética del poema con la virtud moral del protagonista, y se quiere que aquélla dependa de ésta". Los que han estudiado la poesía gauchesca como un grupo de obras tratan a los autores individualmente y se detienen más bien en lo específico de cada obra. Para una definición del género gauchesco se plantea la tarea opuesta, es decir la fijación y definición de esos rasgos comunes a toda la poesía gauchesca. Sus diferencias interesan aquí menos que sus simpatías, y su calificación - estética o moral - resulta totalmente prescindible. Así como tan insecto es la pulga como la abeja, tan género es la sátira, que Lugones tacha de género vil, como la epopeya, y tan novela es La conquista de Bizancio

25 Ibid., pp. 279-280.

26 Ibid., p. 278.

27 L. Lugones, El payador, op. cit., p. 1235. 
de Vargas Vila como el Quijote de Cervantes. Lo que importa para los fines de su definición genérica es lo que acerca a esas obras diferentes y nos permite incluirlas en un mismo grupo y no lo que las separa.

Para definir el género de Martin Fierro, Martínez Estrada descarta la forma y el lenguaje del poema, y para Borges el poema de Hernández es una novela "descontando el accidente del verso". Y sin embargo ya hemos visto que definir la forma exterior de una obra es haber recorrido la mitad del camino hacia la fijación de su género. Su omisión ha posibilitado encontrar en el Martín Fierro una novela: no hubiera sido difícil encontrar cualquier otro género ( $y$ en rigor esto último se ha hecho indiscriminadamente).

Si la materia de una obra por sí sola no define su identidad genérica, tampoco la forma abstraída de la materia que la determina y genera es suficiente para fijar una obra en un género determinado. El género de una obra resultaría - como ha indicado Claudio Guillén- del maridaje entre una materia determinada y una forma determinada: "The important corollary, as far as genres are concerned, is the fact that a preexistent form can never be simply 'taken over' by the writer or transefrred to a new work. The task of form-making must be undertaken all over again. The writer must begin once more to match matter to form, and to that end he can only find a very special sort of assistance in the fact that the fitting of matter to form has already taken place. To offer this assistance is the function of genre'". ${ }^{28}$ Tal definición plantea, sin embargo, un problema de perspectiva: desde el punto de vista del escritor el interrogante del género se presenta como el posible modelo que mejor se ajusta a la obra individual que se propone escribir; desde el punto de vista del crítico, en cambio, esa obra forma ya parte de un grupo de obras con las cuales comparte ciertos rasgos distintivos y unificantes. "Looking backward" —resume concisamente Claudio Guillén-, "a genre is a descriptive statement concerning a number of related works. Looking forward, it becomes above all an invitation to the matching (dynamically speaking) of matter and form". ${ }^{29}$ Es indudable que Hernández conocía las obras de Hidalgo, Ascasubi, Del Campo y Lussich y que veía en ellas una invitación para la construcción de su poema. En la "Carta aclaratoria" de 1872 se alude a esas obras. Algunas veces de manera oblicua: "Quizá la empresa habría sido para mí más fácil, y de mejor éxito, si sólo me hubiera propuesto hacer reír a costa de su ignorancia, como se halla

28 Claudio Guillén, "On the Uses of Literary Genre" en Literature as System; Essays toward the' Theory of Literary History (Princeton University Press, 1971), p. 111. Véase también los ensayos "Toward a Definition of the Picaresque" y "Genre and Countergenre: The Discovery of the Picaresque".

29 Ibid., p. 111. 
autorizado por el uso, en este género de composiciones". ${ }^{30}$ Más adelante la alusión es directa: "Por lo demás, espero, mi amigo, que Ud. lo juzgará con benignidad, siquiera sea porque Martín Fierro no va de la ciudad a referir a sus compañeros lo que ha visto y admirado en un 25 de mayo $u$ otra función semejante, referencias algunas de las cuales, como el Fausto y varias otras, son de mucho mérito ciertamente, sino que cuenta sus trabajos, sus desgracias, los azares de su vida de gaucho, y Ud. no desconoce que el asunto es más difícil de lo que muchos se lo imaginarán". ${ }^{31}$ Hernández, pues, no solamente conocía muy bien "este género de composiciones": en algunas de ellas reconocía mérito suficiente para considerarlas modelo formal de su poema. Reconocido el modelo, Hernández, como todo escritor que se reconoce en una tradición, lo adopta sólo parcialmente, adaptándolo, reajustándolo, a las nuevas necesidades y funciones intuidas en su tratamiento individual del modelo:

Yo he conocido cantores

Que era un gusto el escuchar;

Mas no quieren opinar

$\mathrm{Y}$ se divierten cantando;

Pero yo canto opinando,

Que es mi modo de cantar.

Ya Lugones, en El payador, observó que la obra de Antonio Lussich hạbía servido de modelo inmediato al poema de Hernández y agregaba: "Gallardos y generalmente apropiados al lenguaje y peculiaridades del campesino, los versos del señor Lussich formaban cuartetas, redondillas, décimas y también aquellas sextinas de payador que Hernández debía adoptar como las más típicas".32 También Borges reconoce en Lussich al verdadero precursor de Hernández y en su ensayo El Martín Fierro señala estrechas paralelas entre los textos de Lussich y el texto de Hernández: paralelas que indican no solamente una afinidad y atracción hacia el modelo empleado por Lussich, sino además un tono en el cual Hernández reconoce la voz de Martín Fierro. Lussich puede ser el precursor más inmediato de Hernández, pero la entonación que Hernández oye en los versos de Lussich ya reverbera en los Diálogos patrióticos de Hidalgo. "En ellos" —escribe Borges_ "Bartolomé Hidalgo descubre

30 José Hernández, "Carta aclaratotia" en Poesia gauchesca. Edición y prólogo de J. L. Borges y A. Bioy Casares (México, Fondo de Cultura, 1955), Vol. II. p. 576 .

31 Ibid., p. 577.

32 Leopoldo Lugones, El payador, p. 189, citado por Borges en El Martín Fierro (Buenos Aires, 1953), pág. 17. 
la entonación del gaucho". Y agrega: "En mi corta experiencia de narrador he comprobado que saber cómo habla un personaje es saber quién es, que descubrir una entonación, una voz, una sintaxis peculiar, es haber descubierto un destino. No repetiré líneas de Hidalgo; inevitablemente cometeríamos el anacronismo de condenarlas, usando como canon las de sus continuadores famosos. Básteme recordar que en las estrofas ajenas que citaré, estará de algún modo la voz de Hidalgo, inmortal, secreta y modesta". ${ }^{33}$

Desde el punto de vista de Hernández, entonces, las obras de los poetas gauchescos que le preceden forman "un grupo de composiciones" en las cuales el autor del Martín Fierro vio un modelo, "una invitación pata la creación de su poema", un géneto que se adecuaba a la visión de mundo y destino de su personaje. Lo que Hernández vio con relativa claridad y lucidez se convirtió, para sus críticos, en difícil problema. Parte de la dificultad emerge del empeño en adscribir al poema dentro de un género tradicional y del equívoco supuesto e inconfesado temor de que fuera de esos géneros consagrados el poema quedaría descastado. Hasta ahora, con alguna excepción, se ha buscado definir el géneto literario del Martín Fierro con afán polémico o con propósitos que trascienden su condición de obra literaria. De allí que al estudiar aspectos más particulares de la obra - lengua y estilo, procedimientos y recursos, personajes y narrador, asunto y tema, estructura y argumento- se abandone la definición genérica de la que se parte para examinar esos aspectos aisladamente, como si la cuestión de su género importara solamente pot su mero valor clasificatorio. Sólo en contados casos se ha intentado relacionar los problemas que plantea el estudio del poema con el género que se le atribuye. Tal vez porque hasta ahora los géneros propuestos se resisten a proporcionar al crítico instrumentos y criterios de trabajo para una solución más eficaz de esos problemas. El valor de un género gauchesco como categoría literaria que incluye tanto el poema de Hernández como los demás poemas que tradicionalmente reconocemos como "gauchescos", residiría, precisamente, en la capacidad de ese género de suministrar respuestas más convincentes a los varios interrogantes que presenta el estudio del Martinn Fierro. Si partimos de la noción de la gauchesca como género literario, el problema mismo del género del poema de Hernández se replantea de manera diferente. Ya no tenemos que subordinar y sacrificar su realidad textual a un lecho de Procusto (épica, novela, drama, etc.) en el cual la mutilación es inevitable. Al fin y al cabo un género literario of rece ciertas posibilidades que el escritor adopta

33 Jorge Luis Borges, o.c.s p. 11. 
porque son las que mejor se avienen a sus propósitos. Si Hernández escogió para la materia de su obra esa forma con que hoy la conocemos fue, indudablemente, porque el poema gauchesco convenía mejor a esa materia y a sus intenciones literarias. Cuando un escritor no encuentra entre los modelos a su disposición la forma o género adecuado para dar expresión a sus intuiciones, inventa formas nuevas. Tal habria sido el caso de Hidalgo. Si esa forma es empleada por otros autores que la adoptan modificándola y desarrollándola, se ha establecido un modelo que inicia, que puede iniciar, un nuevo género literario. En mayor o menor medida, Hidalgo, Ascasubi, Del Campo y Lussich fueron los modelos en los que se apoyó Hernández para hacer su poema. El valor de tal constatación reside en el hecho de que, contrariamente a lo que creía Lugones, el Martín Fierro está más cerca del Santos Vega que de la Divina Comedia o de cualquier poema épico y, para el caso, que de cualquier novela. El género de una obra no es un hecho que se define a posteriori: nace $y$ está contenido en el acto mismo de la creación. El poema de Hernández comparte, con los demás poemas de su género, rasgos y características que estudiados en su conjunto nos darian una poética del género. Tal empresa rebasa los límites de este trabajo. Podemos, sin embargo, anotar algunos puntos de partida para la formulación de esa poética. Su valor consistiría, sobre todo, en anticipar algunas respuestas que el concepto de la gauchesca como género literario puede contribuir a problemas largamente polemizados en relación al Martín Fierro. Recorramos brevemente dos de esos problemas desdé el concepto de la gauchesca como género literario: los orígenes del género y su peculiarísimo estilo literario.

\section{ORÍGENES:}

Todo estudiante de la gauchesca sabe que entre los aspectos más estudiados y discutidos en torno a esta poesía el de los orígenes ha ocupado en especial la atención de críticos y comentaristas. El problema puede centrarse en el siguiente interrogante: ¿es la poesía gauchesca una derivación o continuación de la poesía oral de los payadores, como quería Rojas, o es una creación de índole exclusivamente literaria? Menéndez y Pelayo fue el primero en observar que los poetas gauchescos no podían ser clasificados como payadores o poetas populares: "hay en sus obras" -agregaba - "mucho dilettantismo artístico, aunque la fibra popular persiste". También . Oyuela había distinguido entre la poesía de los payadores y la de los poetas gauchescos, pero la ofensiva definitiva contra la tesis payadoresca vino de Borges: "Algunos historiadores de nuestra literatura 
- Ricardo Rojas es el ejemplo más evidente - quieren derivar la poesía gauchesca de la poesía de los payadores o improvisadores profesionales de la campaña. La circunstancia de que el metro octosílabo y las formas estróficas (sextina, décima, copla) de la poesía gauchesca coincidan con las de la poesía payadoresca parece justificar esta genealogía. Hay, sin embargo, una diferencia fundamental. Los payadores de la campaña no versificaron jamás en un lenguaje deliberadamente plebeyo y con imágenes derivadas de los trabajos turales; el ejercicio del arte es, para el pueblo, un asunto serio y hasta solemne. La segunda parte del Martín Fierro nos ofrece, a este respecto, un no señalado testimonio. El poema entero está escrito en un lenguaje rústico; en los últimos cantos, el autor nos presenta una payada en una pulpería y los dos payadores olvidan el pobre mundo pastoril en que viven y abordan con inocencia o temeridad grandes temas abstractos: el tiempo, la eternidad, el canto de la noche, el canto del mar, el peso y la medida. Es como si el mayor de los poetas gauchescos hubiera querido mostrarnos la diferencia que separa su trabajo deliberado de las irresponsables improvisaciones de los payadores". ${ }^{34}$ Martínez Estrada ha estudiado las fuentes populares y cultas del Martin Fierro y ha señalado, entre estas últimas, a autores como Calderón, Lope y Espronceda. Obras como La vida es sueño, El alcalde de Zalamea, El Isidro y El diablo mundo —sugiere Martínez Estrada- llegaron a Hernández a través de Hidalgo, Ascasubi y, sobre todo, Lussich en quienes ejercieron una inequívoca influencia. Pero la posibilidad de que Hernández haya leído directamente $E l$ Isidro de Lope tampoco se descarta del todo. ${ }^{35}$ La sola lectura de los fragmentos de El Isidro que Martínez Estrada transcribe bastaría para mostrar hasta qué grado la poesía gauchesca se debe a sus fuentes literarias tanto como a la realidad del gaucho que intenta representar. La conclusión de Martínez Estrada es terminante: "El poema de Lope prefigura al de Hernández por su forma sentenciosa, en que la quintilla concluye por lo regular con un refrán o un dicho a la manera típica de la sexteta. Contiene, asimismo, escenas tales como la de los peregrinos que cuentan sus vidas y consejos (Canto VI) y batallas entre cristianos y moros (Cantos VIII y IX), comunes

34 Jorge Luis Borges, o.c., pp. 9-10.

35 Véase en especial el capítulo "Conexión temática del Martín Fierro con otras obras", de Muerte y transfiguración de Martín Fierro, tomo II, pp. 298-320. En p. 300, escribe Martínez Estrada: "No es arbitrario suponer un influjo ditecto del poema de Lope sobre el de Hernández. La obra fue muy difundida entre los labradores, que adoptaron el santo como patrono desde el establecimiento de los primeros hortelanos en el partido de San Isidro, precisamente, donde estaban ubicadas las fincas de los Pueyrredón, y en cuya iglesia parroquial se celebraban fiestas anuales con lectura de fragmentos del poema de Lope". 
en el Santos Vega y en el Martin Fierro". 36 Pero si la poesía gauchesca no es una derivación o un remedo de la poesía de los payadores, es, qué duda cabe, una recreación por un poeta culto del estilo del gaucho y de la habilidad de cantor del payador. El poeta gauchesco no es un payador pero se propone crear la ilusión de serlo. Sin excepción, los narradores o cantores de los poemas gauchescos son payadores. Tal mimesis representa la explicación más inmediata del uso del mismo metro que manejaban los payadores y constituye un primer esfuerzo hacia la transcripción literaria de la poesía oral de los payadores. El payador, para demostrar que era poeta, debía cantar en un español de apariencia culta diferente al que hablaba. El poeta gauchesco hace lo opuesto: hombre culto, escribe en un español de apariencia popular. La poesía gauchesca necesita por igual de un poeta culto y de la realidad de un payador que canta para gauchos y así lo comprende Borges cuando escribe: "Cabe suponer que dos hechos fueron necesarios para la formación de la poesía gauchesca. Uno, el estilo vital de los gauchos; otro, la existencia de hombres de la ciudad que se compenetraron con él y cuyo lenguaje habitual no eta demasiado distinto". Y agrega: "La poesia gauchesca, desde Bartolomé Hidalgo hasta don José Hernández, se funda en una convención que casi no lo es, a fuerza de ser espontánea. Presupone un cantor gaucho, un cantor que, a diferencia de los payadores genuinos, maneja deliberadamente el lenguaje oral de los gauchos y aprovecha los rasgos diferenciales de este lenguaje, opuesto al urbano". ${ }^{37}$ Esta convención, sin embargo, es el vértice que relaciona poesía payadoresca y poesía gauchesca. A pesar de los repetidos esfuerzos por probar el carácter novelístico del Martin Fierro y otros poemas gauchescos, el poeta gauchesco emplea el verso y no la prosa. En esta aparente inconsecuencia se manifiesta la sujeción de la poesía gauchesca al modelo que recrea, sujeción que no es otra que la de ciertos géneros relativamente recientes con formas primitivas de la literatura popular $u$ oral en las que se inspiran. El formalista ruso Viktor Schklovsky ha observado que las nuevas formas de arte son. "simplemente la canonización de géneros inferiores o infraliterarios. Las novelas de Dostoyevski, por ejemplo, constituyen una serie de novelas de crimen, de romans à sensation ennoblecidas; las composiciones líricas de Pushkin proceden de versos de álbum; las de Blok, de cantos de gitanos; las de Mayakovsky, de poesías de revistas satíricas". ${ }^{38}$ La solución que of rece Schklovsky permite reconocer los prolegómenos

36 Ezequiel Martínez Estrada, o.c., II, 301.

37 Jorge Luis Borges, o.c., p. 10.

38 Viktor Schklovsky, O T'oriyt prozy, 1925. Citado por Wellek y Warren en Teoria literaria (Madrid, 1959), p. 283. 
de un género sin subordinar éste a aquéllos, sin derivar el uno de los otros, sin confundir un género literario con su género infraliterario. Pero al mismo tiempo la relación género-infragénero posibilita una mejor comprensión de cómo están hechos los poemas gauchescos, de la distancia que el poeta gauchesco toma respecto al payador y, en el mismo movimiento, de la relación que guarda el organismo diferenciado respecto a su embrión. El payador debía demostrar que podía versificar como el poeta culto; el poeta se propuso mostrar que podía cantar como el gaucho. El esfuerza del primero es una destreza de improvisación, una habilidad oral; el esfuerzo del segundo es una empresa literaria y como "para hacer de un objeto un hecho artístico es necesario extraerlo de la serie de los hechos de la vida", ${ }^{39}$ el poeta gauchesco crea una convención, un cantor que ya no puede ser payador pero que, como todo signo respecto a la cosa que representa, crea en el lector la ilusión literaria del objeto representado, en este caso del payador. Ya se sabe que "las leyes del lenguaje poético son diferentes a las leyes del lenguaje práctico"; ${ }^{40}$ de la misma manera, la poesía de los payadores está gobernada por leyes diferentes a las que rigen la creación literaria de la poesía gauchesca. La primera quiere crear la ilusión de un poeta culto, la segunda, de un poeta popular; la primera, es oral, la segunda escrita; la primera es cultivada por gauchos, la segunda, por poetas cultos. Para lograr la ilusión de un poeta popular, que es gaucho e improvisa, el poeta gauchesco está obligado a reconstruir -al nivel de la literatura - el escenario y la utilería del payador. Su tarea consiste en encontrar los procedimientos y recursos literarios para esa reconstrucción. Inevitablemente debe dirigirse a su modelo y entablar una relación semejante a la que ha existido siempre entre modelo y representación. Cuando el primero es un género o infragénero literario es indudable que algunos procedimientos o técnicas del modelo son adoptadas o adaptadas en su representación. Piénsese en las novelas de caballería respecto al Quijote, en las novelas de crimen respecto a Dostoyevsky, en la novela de misterio respecto a Dickens, ${ }^{41}$ en los $m i$ drasbim respecto a algunos relatos de Agnón. En los ejemplos citados una forma ha sido trasvasada a una forma nueva, una forma proporciona ciertos elementos para crear una forma nueva. De esta constatación emerge la necesidad de confrontar modelo y representación, no a los fines de una

39 Viktor Schklovsky, "La construcción de la 'nouvelle' y de la novela" en Teoria de la litsratura de los formalistas rusos (Buenos Aires, 1965), p. 137. 40 Viktor Schklovsky, "Art as Technique" en Russian Formalist Criticism; Four Essays (University of Nebraska Press, 1965), p. 11.

${ }^{41}$ Véase el artículo de Viktor Schklovsky, "The Mystery Novel: Dicken's Little Dorrit", en Readings in Russian Poetics: Formalist and Structuralist Views (MIT Press, 1971), pp. 220-226. 
mera comparación de semejanza o desemejanza sino con el objeto de estudiar lo que ésta debe a aquél, lo que la forma nueva ha preservado de la vieja. Generalmente se ha insistido en las diferencias. Lo que proponemos ahora no es volver a la tesis de Ricardo Rojas, sino a la necesidad de comprender mejor el funcionamiento de los poemas gauchescos desde el modelo de los payadores que los inspira. Esa comprensión debe partir de las diferencias para encontrar, ya sin riesgo de asimilar la gauchesca a la poesía de los payadores, lo que la mecánica del poema gauchesco debe a su modelo. El poeta gauchesco parte de una realidad: la presencia de payadores que versifican en octosílabos. Apoyándose en la existencia de esos gauchos cantores, crea personajes que asumen el rol de gauchos cantores y versifican en el mismo metro. En el cielito "El gaucho de la Guardia del Monte", el cantor de Hidalgo declara en los primeros versos: "Ya que encerré la tropilla/ y que recogí el rodeo/ voy a templar la guitarra/para explicar mi deseo." También el personaje de Hernández habla desde su condición de payador: "Aquí me pongo a cantar/ al compás de la vigüela". Pero el poeta gauchesco no se propone imitar al payador sino recrearlo literariamente. Un primer paso para lograrlo es presentar al narrador del poema como payador que versifica en el mismo metro que usaban los payadores. Los pasos subsiguientes tienden a alejarse del modelo: el payador escoge temas abstractos sobre los cuales especula con prurito de filósofo avesado y en un estilo de apariencia culta; el poeta gauchesco cuenta una "historia", "un caso" o "deseo" en un estilo más próximo al habla de los gauchos que al lenguaje rebuscado de los payadores.

\section{EstILO:}

Lo que interesaba al poeta gauchesco no era el arte del payador sino el destino del gaucho: debió crear una doble ilusión - primero un gaucho que canta como cantaban los payadores; después, impresiones y vidas de gauchos narradas por gauchos. Para conseguir lo primero adopta el metro de los payadores; para lo segundo, crea un estilo que no es ni el copetudo de los payadores ni el desflecado de los gauchos, sino una convención literaria que preserva algo de los unos y no poco de los otros. Esta convención crea la ilusión del habla de los gauchos, una ilusión no diferente a la de cualquier hecho literario en relación al mundo que representa, aunque luego el lector tenga la certeza de oír al gaucho. El propio Ascasubi en el prólogo a Paulino Lucero escribió a propósito de los habitantes de la campaña: "me he valido en mis escritos de su 
propio idioma" ${ }^{\prime 2}$ y ya se sabe que no pocos estudiosos de la gauchesca vieron en el lenguaje de esta poesía documentos literarios de un hipotético "dialecto gauchesco". Peto Ascasubi, que conoció muy de cerca al gaucho, sintió la necesidad de rectificarse; en la nota "Al lector" del Santos Vega escribe: "Este libro que para muchos será sólo el eco de los cantos del Gaucho, y que para otros será una violación de las reglas literarias de su lenguaje..." 43 Una violación en cuyo proceso el habla de los gauchos se convierte en literatura, una violación que no es sino el esfuerzo del poeta por recrear en un medio diferente - en la irrealidad del artela realidad de ese mundo vital que se busca trasponer. Consciente o inconscientemente, los poetas gauchescos hicieron uso de un procedimiento literario ya presente en el libro de los Jueces donde un miembro de la tribu de Benjamín es reconocido por el modo peculiar de pronunciar ciertos fonemas. A este recurso de estilo que intenta crear la ilusión de un lenguaje oral los formalistas rusos llamaron skaz. Hasta qué punto la poesía gauchesca es una convención no diferente -en cuanto procedimiento estilístico - al skaz empleado por Gogol en El capote, se manifiesta en las inconsecuencias en la grafía anotadas por Tiscornia y Martínez Estrada: las formas para y pa, fuego y juego, donde y ande, bueno y güeno alternan indistintamente, como si el poeta hubiera querido subrayar el carácter de invención del lenguaje por él troquelado. También las voces cultas salpicadas a lo largo del Martín Fierro y los demás poemas gauchesćos representan algo así como un lapso que revela su condición de convención literaria. Borges intentará crear una convención semejante respecto al lenguaje del compadre. En "Hombre de la esquina rosada", al lado de voces y giros que proceden del habla del compadre aparecen otras en las cuales reconocemos las destrezas de estilo del autor de Ficciones. ${ }^{44}$ De esa fusión emerge un lenguaje que está tan cerca del compadre como del estilo de la prosa más tardía de Borges, un lenguaje que además de reconstruir el habla de los compadritos descubre el estilo de su inventor. Amado Alonso caló hondo cuando escribió a propósito de "Hombre de la esquina rosada": "El problema poético planteado en este cuento y bien resuelto es el de dar la sensación de lenguaje oral a la vez que se procede con la mayor dignidad literaria". ${ }^{45} \mathrm{Ni}$ los compadres hablaban como los hizo hablar Borges, ni los gauchos como los hace ha-

12 Poesía gauchesca, o. c., I, 36.

43 Ibid., p. 305.

44 En nuestro artículo "Dos soluciones estilísticas al tema del compadre en Borges y Cortázar (Exilio, vol. 6, No. 1, primavera de 1972) hemos intentado estudiar la solución alcanzada por Borges en "Hombre de la esquina rosada" respecto al habla del compadre.

45 Amado Alonso, Materia y forma en poesía (Madrid, Gredos, 1960), p. 347. 
blar la poesía gauchesca. $Y$ sin embargo, en un caso $y$ en otro se ha alcanzado un grado de autenticidad que solamente acentúa las diferencias y distancias entre las leyes que gobiernan la escritura y las que rigen el lenguaje oral. Un registro magnetofónico de las hablas del gaucho y del compadre hubiera dado a lo sumo material informativo para el lingüista. Para "dar la sensación de un lenguaje oral" la escritura selecciona y organiza con criterios diferentes. De la misma manera que la imagen musical de una tormenta no es la tormenta, la poesía gauchesca no es el habla de los gauchos. En ambos casos, sin embargo, se ha conseguido una ilusión producida por un sistema de signos que procede incorporando algunas semejanzas (el trueno de la tormenta, parte del léxico y algunos giros del habla del gaucho) con la ayuda de las cuales se cumple una primera verosimilitud, un punto de apoyo sobre el cual hace palanca el nuevo medio - música, escritura- para levantar un orden imaginario, un mundo, más o menos realista, pero ya definitivamente dislocado de la realidad y que se debe más a su sistema de signos que a las cosas que esos signos representan.

Ningún crítico del Martin Fierro reunió, como Martinez Estrada, un acopio semejante de elementos de juicio indispensables para la definición del género literario del poema; ninguno estuvo tan cerca de la formulación de una poética del género gauchesco como el autor de Radiografia de la Pampa. Sus oscilaciones entre géneros más convencionales como novela, poema dramático, poema lírico, novela picaresca, ${ }^{46}$ indican que tal vez ninguno de ellos lo satisfacía del todo. En el capítulo dedicado a las influencias literarias es donde más se acerca al reconocimiento de la poesía gauchesca como el género más próximo y que más conviene al Martin Fierro. Después de estudiar las posibles huellas de la literatura española en el poema de Hernández, Martínez Estrada concluye sin embargo: "Ninguna labor más vacía que la de buscar en el Martín Fierro rastros de influencias literarias, fuera de los poemas gauchescos". Y agrega: "Si Lope y Espronceda se nos presentan como sus precursores en el estilo de contar; si de la novela picaresca pasa al Poema la suerte del huérfano en su lucha por la vida, rasgos de carácter que se tipifican más

\footnotetext{
46 En páginas 303-304 del segundo tomo de Muerte y transfiguración, escribe: "Pero todavía muchísimo más notable y hasta tangible es la influencia de la novela - y de la tradición- picaresca sobre el Martin Fierro. No habría capricho ni exceso en clasificar la Obia dentro de ese género, porque en realidad contiene todos sus elementos típicos. Personajes como Vizcacha, el Hijo Segundo y Picardía encajan enteros en la picaresca, y en grandes porciones también de sus vidas y actitudes Martín Fierro, Cruz y el Hijo Mayor. A esta perceptible consanguinidad, tanto como al sabor castizo del lenguaje, debió remitirse Unamuno al afirmar con todo acierto que el Poema es un vástago de la literatura española y que no puede ser entendido a fondo fuera de ella".
} 
que en la psique en la aventura; si de Calderón se superpone un sentico filosófico y ético y que no se ha asimilado por completo al plasma de la obra, de los poemas gauchescos derivan todos los elementos estructurales, ambientales y biográficos." 47 Si el Martín Fierro comparte con los demás poemas gauchescos un asunto, un repertorio de artificios, un Kunstwollen o voluntad artística, un propósito semejante de provocar en el lector ciertos efectos, aunque éstos varíen según el tema particular de cada obra, y una forma exterior relativamente uniforme, hay que concluir que en esos rasgos distintivos se definen inequívocamente los ingredientes de un género literario. Así lo reconoce Martínez Estrada cuando distingue entre lo que el Martín Fierro debe a su género y lo que lo trasciende: "Desde el primero hasta el último verso, el autor del Martin Fierro nos mantiene en una altura jamás alcanzada por sus predecesores, y lo que ya se nos había contado reaparece ante la imaginación por primera vez. Esto no proviene simplemente de que el Poema está construido en tres dimensiones, faltándoles a los otros la de profundidad, sino de que sobre la urdimbre vieja Hernández ha bordado con una técnica muy personal; de que en odres viejos puso vino nuevo". ${ }^{48}$

JaIme AlazRaki

University of California, San Diego.

$4 \pi$ Ezequiel Martínez Estrada, Muerte y transfiguración de Martin Fierro, II, 316 (subrayado nuestro).

48 Ibid., págs. 316-317. 